\title{
EFFECT OF NUTRIENTS AND MEDICINES ON SURFACE OF COMPOMER
}

\section{ABSTRACT}

Objectives: The objective of this study is to examine the effect of nutrients and medicines frequently consumed by children on the surface roughness of the PolyacidModified Composite Resin (compomer), a restorative material typically used in pediatric dentistry.

Materials and Methods: VOCO Glasiosite ${ }^{\circledR}$ Caps compomer was used as the restoration material. Seven control groups consisting of nutrients and medicines frequently consumed by children from 0-6 years (Group 1: Ferro Sanol ${ }^{\circledR}$ B $(150 \mathrm{ml})$ syrup, Group 2: Augmentin ${ }^{\circledR}-B I D(400 \mathrm{mg} / 57 \mathrm{mg})$ suspension, Group 3: Calpol ${ }^{\circledR}$ (120 mg/150 ml ), Group 4: Bebelac ${ }^{\circledR}$ Gold 5 follow-on milk, Group 5: Danino ${ }^{\circledR}$ strawberry yogurt, Group 6: Nesquik ${ }^{\circledR}$ chocolate milk, Group 7: Cappy ${ }^{\circledR}$ orange juice) were formed and their $\mathrm{pH}$ values were measured. Compomer discs were created and their initial surface roughness was measured by Bruker® Stylus Profilometer. Taking into consideration its annual usage period, compomer material was brought in contact with solutions. Then the roughness test was repeated. SEM images of each compomer material were taken and compared with the control group.

Results: The evaluation of the medicine group revealed that Ferro Sanol® B displays the highest level of surface roughness difference $(23.3 \mathrm{~nm})$. As to the nutrients group, Cappy ${ }^{\circledR}$ orange juice showed the highest surface roughness difference $(21.4 \mathrm{~nm})$. SEM images support these findings.

Conclusions: The effect of the solutions on the surface roughness of filling surfaces increases depending on their acidity. However, it is believed that $\mathrm{pH}$ solely does not have any impact. These studies should be supported by corrosion experiments.

Keywords: Surface properties, compomers, foods, drug utilization.
*Tamara Pelin Gündoğdu Özdal ${ }^{1}$ (D) Gülsüm Duruk ${ }^{1}$

ORCID IDs of the authors: T.P.G.Ö. 0000-0002-3154-5180 G.D. 0000-0002-6756-6637

${ }^{1}$ Department of Pediatric Dentistry, Faculty of Dentistry, Inonu University, Malatya, Turkey

Received : $: 27.12 .2018$

Accepted : :02.04.2019

How to Cite: Özdal TPG, Duruk G. Effect of Nutrients and Medicines on Surface of Compomer. Cumhuriyet Dent J 2019;22:2: 


\section{INTRODUCTION}

Surface properties of restorative materials used in dentistry that are in contact with the oral environment affect the endurance of restoration. Dental materials are used not only for treatment but also to provide long-term aesthetics. Thus, the materials are desired to be as durable and smooth as the tooth surface..$^{1-3}$ Not only the corrosion and roughness on the teeth but also surface irregularities of the restoration materials cause plaque retention and therefore secondary caries, damage to the opposing teeth, and periodontal diseases due to restorations incompatible with the gingiva. ${ }^{4-6}$ Long-term success of the restoration depends on a variety of factors such as foreign materials on the surface, micro-mechanical properties of the material, way of implementation, duration of the polymerization, and porosity. ${ }^{7}$ In addition, acidic foods and beverages cause porosities on the surface of the material in the long term. ${ }^{8}$ Different types of fruit juice, yogurt, and formula in particular that are frequently used in childhood and medicines that are high in acidity were shown to be capable of affecting the restorative materials as well as causing corrosion on the tooth surface. ${ }^{9-11}$ Surface hardness of the restorative materials used in pediatric dentistry were shown to decrease in case of contact with food having low $\mathrm{pH}$ values. ${ }^{12,13}$ Since the nutrition of children differs from that of adults, the number of studies on the impact of food and medicines on the compomer material used in pediatric dentistry is not sufficient. ${ }^{14}$

Today, compomer material is widely used in pediatric dentistry. This material is capable of releasing fluoride, highly resistant to abrasion, fracture and bending, easily shaped, can be polished, and meets aesthetic expectations. The objective of this study is to examine the impact of food and medicines frequently consumed by children on the surface roughness of the compomer material.

\section{MATERIALS AND METHODS}

Medical suspensions and liquid nutrients that are frequently consumed by children between 0-6 years were selected. Seven groups consisting of 3 medicine groups and 4 nutrient groups were formed. Group 1: Ferro Sanol® B (150 ml) syrup, Group 2: Augmentin ${ }^{\circledR}-B I D ~(400 \mathrm{mg} / 57 \mathrm{mg})$ suspension, Group 3: Calpol® $(120 \mathrm{mg} 150 \mathrm{ml})$, Group 4: Bebelac ${ }^{\circledR}$ Gold 5 follow-on milk, Group 5: Danino ${ }^{\circledR}$ strawberry yogurt, Group 6: Nesquik ${ }^{\circledR}$ chocolate milk, and Group 7: Cappy ${ }^{\circledR}$ orange juice. Ingredients of the nutrients and medicines are shown in Tables 1 and 2. $\mathrm{pH}$ values and annual usage periods (consultated with pediatricians) of the samples from nutrient and medicine groups are shown in Table 3.

Table 1. Nutrients used and their ingredients

\begin{tabular}{|c|c|c|}
\hline Nutrients & Manufacturer & Ingredients \\
\hline Bebelac ${ }^{\circledR}$ Gold 5 follow-on milk & Nutricia ${ }^{\circledR}$ & $\begin{array}{l}\text { Skim milk, lactose, whey components, maltodextrin, prebiotic fibers, vegetable } \\
\text { oils, tricalcium phosphate, calcium carbonate, tripotassium citrate, trisodium } \\
\text { citrate, L-ascorbic acid, magnesium chloride, emulgator, taurine, choline } \\
\text { chloride, sodium L-ascorbate, potassium chloride, iron sulfate, zinc sulfate, } \\
\text { DL- } \alpha \text {-tocopheryl acetate, nicotinamide calcium D-pantothenate, } \\
\text { pteroylmonoglutamic acid, copper sulfate, DL- } \alpha \text {-tocopherol, retinyl palmitate, } \\
\text { D-Biotin, cholecalciferol, thiamine hydrochloride, pyridoxine hydrochloride, } \\
\text { riboflavin, cyanocobalamin, potassium iodide, manganese sulphate, } \\
\text { phytomenadione, sodium selenite. }\end{array}$ \\
\hline Strawberry yogurt & Danino $®$ & $\begin{array}{l}\text { Pasteurized and homogenized cow's milk, strawberry preparate (10\%) } \\
\text { [strawberry, sugar, modified starch, black carrot juice concentrate, strawberry } \\
\text { flavorant, stabilizer (carrageenan), acidity regulator (sodium citrates), sugar, } \\
\text { strawberry puree }(0.01 \%) \text {, yogurt culture. }\end{array}$ \\
\hline Nesquik ${ }^{\circledR}$ chocolate milk & Nestle $\mathbb{R}$ & $\begin{array}{l}\text { Pasteurized drinking milk, sugar, cocoa powder (1.1\%), salt,stabilizer } \\
\text { (carrageenan),minerals (iron phosphate, zinc sulfate), flavorant (vanillin), } \\
\text { cinnamon }\end{array}$ \\
\hline Cappy® orange juice & Coca-Cola ${ }^{\circledR}$ & $\begin{array}{l}\text { At least } 50 \% \text { mixed fruit juice from concentrate (orange), water, sugar or } \\
\text { fructose-glucose syrup, flavorants, acidity } \\
\text { regulator (citric acid), vitamin A. }\end{array}$ \\
\hline
\end{tabular}


Table 2. Medicines and ingredients

\begin{tabular}{|c|c|c|}
\hline Medicines & Manufacturer & Ingredients \\
\hline Ferro Sanol® B (150ml) syrup & $\begin{array}{l}\text { Adeka İlaç ve } \\
\text { Kimyasal Ürünler } \\
\text { San. ve Tic. A.Ş. }\end{array}$ & $\begin{array}{l}\text { Ferrous(II)-glycine-sulphate complex, } 43 \mathrm{mg} \text { riboflavin- } \\
\text { sodium phosphate, } 0.32 \mathrm{mg} \text { of Vitamin B1, 0.63 mg of } \\
\text { Vitamin B6 (pyridoxine hydrochloride), Ascorbic acid, } \\
\text { single refined sugar, glucose monohydrate, sorbitol, 95- } \\
98 \% \text { sulphuric acid, orange oil, pear oil, deionized water. }\end{array}$ \\
\hline Augmentin ${ }^{\circledR}$-BID $(400 \mathrm{mg} / 57 \mathrm{mg})$ suspension & GlaxoSmithKline & Amoxicilline 400mg $/ 5 \mathrm{ml}$, Clavulanic Acid $57 \mathrm{mg} / 5 \mathrm{ml}$ \\
\hline Calpol® $(120 \mathrm{mg} / 150 \mathrm{ml})$ suspension & $\begin{array}{l}\text { Abdi İbrahim İlaç } \\
\text { Sanayi ve Ticaret } \\
\text { A.Ş. }\end{array}$ & $\begin{array}{l}\text { Paracetamol, sorbitol solution, strawberry flavor, sucrose, } \\
\text { Nipagin M (methyl parahydroxybenzoate), glycerol, Avicel } \\
\text { rc 591, Carmoisine E 122, xanthan gum, purified water. }\end{array}$ \\
\hline
\end{tabular}

Table 3. Annual usage periods of the samples

\begin{tabular}{|c|c|c|c|}
\hline Samples & pH & Usage time in a year & In-mouth duration time \\
\hline Ferro Sanol® B (150ml) syrup & 2 & $2 \times 12.5$ months Once a year & $2 \mathrm{~min}$ \\
\hline Augmentin ${ }^{\circledR}$-BID $(400 \mathrm{mg} / 57 \mathrm{mg})$ suspension & 6.3 & $2 \times 110$ days 4 times in a year & $2 \min$ \\
\hline Calpol ${ }^{\circledR}(120 \mathrm{mg} / 150 \mathrm{ml})$ suspension & 6 & $3 \times 15$ days 6 times in a year & $2 \min$ \\
\hline Bebelac $\AA$ Gold 5 follow-on milk & 7 & $5 \times 1365$ days & $5 \mathrm{~min}$ \\
\hline Danino ${ }^{\circledR}$ strawberry yogurt & 5.5 & $1 \times 1365$ days & $5 \mathrm{~min}$ \\
\hline Nesquik $®$ chocolate milk & 6.5 & $1 \times 1365$ days & $5 \min$ \\
\hline Cappy® orange juice & 3.5 & $1 \times 1365$ days & $5 \mathrm{~min}$ \\
\hline
\end{tabular}

Distilled water was used as the control group. Glasiosite ${ }^{\circledR}$ Caps compomer (VOCO, Cuxhaven, Germany) was used as the restoration material. The composition for the compomer material determined by the manufacturer is as follows: BIS-GMA, diurethane-dimethacrylate, TEGDMA, BHT, $\quad 77.5 \%$ 2.6-bis (1.1-dimethylethly)-4methylphenol filler. Acidity of all nutrients and medicines was measured by $\mathrm{pH}$ paper strip. Metal plates of $5 \mathrm{~mm}$ width and $2 \pm 0.1 \mathrm{~mm}$ thickness were produced to place the compomer material in. To ensure standardization, A3 was chosen as the color of the compomer material placed in the metal plates. The material was placed in the discs in a way to overflow a bit. Cellulose acetate matrix tape was used for insulation and pressure was applied on the glass plate. As recommended by the manufacturer, the material was polymerized from a single direction for 40 seconds through Monitex ${ }^{\circledR}$ Blue LEX LD-105 Led-C curing light (wavelength 450-470). Each compomer disc was polished for 10 seconds by the same person using 600, 800, and 100 grits silicon carbide discs, respectively. The procedure was repeated by preparing 80 compomer discs, 10 for each group. Each sample was kept at $37^{\circ} \mathrm{C}$ for 24 hours for rehydration. Roughness on the samples was measured over 100 lines with intervals of 10 micrometer through Stylus Profilometer (Dektak 150, Bruker,Santa Barbara, CA) with 2 micrometer probe tip and the values were recorded in nanometer $(\mathrm{nm})$. The solutions were prepared as recommended by the manufacturers. Distilled water was used for solutions to which water should be added. Afterwards, an approximate annual usage period for the solutions was calculated (Table 3). Samples were kept in the solutions whereas the control group in distilled water at $37^{\circ} \mathrm{C}$ in closed containers. Once the soaking was completed, each sample was rinsed with distilled water for 10 seconds and left to dry.

Roughness measurements were repeated. The difference between the two roughness values was calculated and the statistical measurements were performed based on this value. The samples were examined in two separate groups, namely medicines and nutrients. Scanning Electron Microscope (SEM) images of the samples tested for roughness were examined in Inonu University Scientific And Technological Research Center (IBTAM). In SEM imaging, the entire compomer surface was scanned and samples magnified by $2.50 \mathrm{X}$ and $10.00 \mathrm{X}$ which show the best image were collected with $20.00 \mathrm{kV}$ from the area providing the best image.

\section{Statistical Analysis}

Data concerning surface roughness were uploaded to SPSS (version 21.0) software. Shapiro-Wilk test and Paired Sample t-Test was used in the assessment of data. The data were recorded as arithmetic mean \pm standard deviation and level of error was taken as 0.05 . 


\section{RESULTS}

Despite being taken once a year on average, Ferro Sanol ${ }^{\circledR}-\mathrm{B}$, the most frequently used medicine in the medicine group, was found to have the longest in-mouth duration since it is used for 2.5 months. It is followed by $\mathrm{Calpol}^{\circledR}$ and Augmentin $\AA$, respectively. Considering its $\mathrm{pH}$ value, Ferro Sanol ${ }^{\circledR}$ B was found to be the most acidic $(\mathrm{pH}=2)$ medicine.

The evaluation of surface roughness revealed that Ferro Sanol ${ }^{\circledR}$ B displays the highest level of surface roughness difference $(23.3 \mathrm{~nm})(\mathrm{p}<0.01)$, followed by $\quad$ Calpol ${ }^{\circledR} \quad(5.3 \quad \mathrm{~nm}) \quad(\mathrm{p}>0.05)$. Augmentin ${ }^{\circledR}$ displayed values close to the distilled water group (as $1.0 \mathrm{~nm}(\mathrm{p}>0.05)$ (Figure 1).

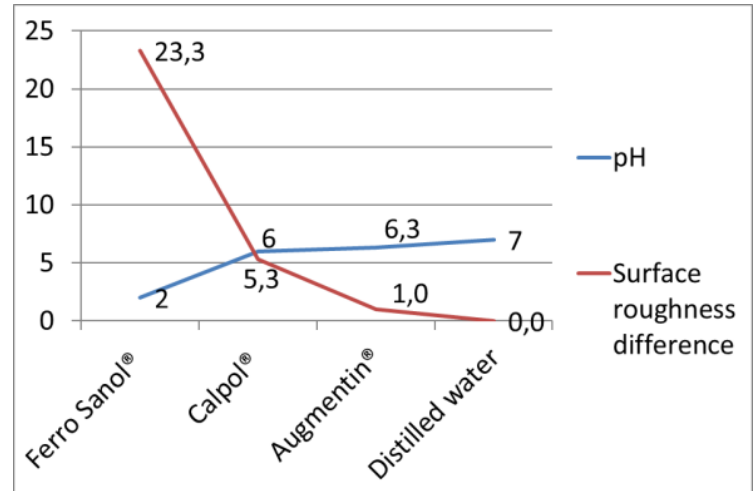

Figure 1. Surface roughness difference and acidity of medicine group

The in-mouth duration of the foods in the nutrient group was taken as 5 minutes when consumed at once. As to the nutrient group, Cappy ${ }^{\circledR}$ orange juice was found to have the highest level of acidity $(\mathrm{pH}=3.5)$ and followed by Danino ${ }^{\circledR}$ strawberry yogurt $(\mathrm{pH}=5.5)$, Nesquik ${ }^{\circledR}$ chocolate milk $(\mathrm{pH}=6)$ and Bebelac ${ }^{\circledR} 5$ follow-on milk $(\mathrm{pH}=7)$ respectively. The evaluation of surface roughness revealed that Cappy ${ }^{\circledR}$ orange juice displays the highest level of surface roughness difference $(21.4 \mathrm{~nm})(\mathrm{p}<0.01)$. Surface roughness and acidity of Danino ${ }^{\circledR}$ strawberry yogurt (13.4 $\mathrm{nm})(\mathrm{p}>0.05)$, Nesquik ${ }^{\circledR}$ chocolate milk $(2.2 \mathrm{~nm})$ $(p>0.05)$, Bebelac $\AA 5$ follow-on milk $(1.8 \mathrm{~nm})$ ( $>0.05$ ) are directly proportional (Figure 2 ). The surface roughness difference caused by all of the solutions on the compomer material are shown in Table 4.

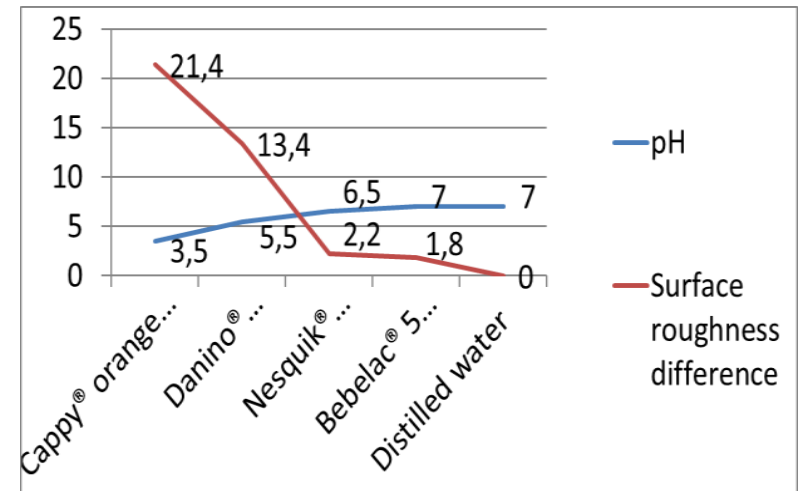

Figure 2. Surface roughness difference and acidity of nutritient group

Table 4. Surface roughness difference caused by all of the solutions

\begin{tabular}{|c|c|c|c|c|c|c|}
\hline \multirow[t]{2}{*}{ Samples } & \multirow[t]{2}{*}{$\begin{array}{l}\text { Before } \\
\text { (average nm) }\end{array}$} & \multirow[t]{2}{*}{$\begin{array}{l}\text { After } \\
\text { (average nm) }\end{array}$} & \multicolumn{2}{|c|}{$\begin{array}{l}\text { 95\% Confidence } \\
\text { Interval of the } \\
\text { Difference }\end{array}$} & \multirow[t]{2}{*}{$\begin{array}{l}\text { Difference } \\
\text { mean }\end{array}$} & \multirow[t]{2}{*}{ p value } \\
\hline & & & & & & \\
\hline Ferro Sanol® B (150ml) syrup & $323.0 \pm 33.5$ & $346.4 \pm 22.8$ & -33.5 & -13.1 & 23.3 & 0.001 \\
\hline Augmentin ${ }^{\circledR}-\mathrm{BID}(400 \mathrm{mg} / 57 \mathrm{mg})$ suspension & $304.2 \pm 22.4$ & $305.1 \pm 33.7$ & -10.5 & 8.50 & 1.0 & 0.817 \\
\hline Calpol® $(120 \mathrm{mg} / 150 \mathrm{ml})$ suspension & $289.3 \pm 27.2$ & $294.6 \pm 35.3$ & -16.7 & 6.1 & 5.3 & 0.320 \\
\hline Bebelac $\AA$ Gold 5 follow-on milk & $312.9 \pm 31.8$ & $314.8 \pm 43.8$ & -14.9 & 11.3 & 1.8 & 0.764 \\
\hline Danino ${ }^{\circledR}$ strawberry yogurt & $294.3 \pm 31.5$ & $307.6 \pm 23.3$ & -27.3 & 0.5 & 13.4 & 0.057 \\
\hline Nesquik ${ }^{\circledR}$ chocolate milk & $222.5 \pm 25.0$ & $224.6 \pm 36.2$ & -13.1 & 8.7 & 2.2 & 0.658 \\
\hline Cappy® orange juice & $213.0 \pm 33.6$ & $234.6 \pm 43.1$ & -30.8 & -11.9 & 21.4 & 0.001 \\
\hline Distilled water & $302.1 \pm 22.2$ & $302.1 \pm 22.2$ & - & - & 0.0 & - \\
\hline
\end{tabular}

SEM images of the samples kept in solutions were taken. SEM images support that acidity and surface roughness are in direct proportion. SEM images of the material on which Ferro Sanol ${ }^{\circledR}$ B was applied revealed a considerable degree of roughness compared to the ones on which Calpol ${ }^{\circledR}$ and Augmentin ${ }^{\circledR}$-BID were applied. Ferro Sanol® B applied sample was observed to have pits on the surface and distortions in the flat surface form. The roughness ratio was observed to decrease with a significant difference in the Calpol ${ }^{\circledR}$-applied sample. Surface properties of Augmentin ${ }^{\circledR}$-BID-applied sample was similar to that of the control group. When SEM images of nutrients were examined, samples on which foods with low $\mathrm{pH}$ values were applied showed higher surface roughness. Cappy ${ }^{\circledR}$ orange juice-applied sample showed the highest surface roughness which is supported by SEM images. Acidity of Danino ${ }^{\circledR}$ strawberry yogurt $(\mathrm{pH}=5.5)$ destroyed 
the integrity of the compomer material. SEM image of the Nesquik ${ }^{\circledR}$ chocolate milk-applied compomer material did not reveal an intense roughness. Surface roughness difference of 2.2 $\mathrm{nm}$ between samples and acidity $(\mathrm{pH}=6.5)$ close to that of the distilled water group was observed supported by SEM images. Having a neutral $\mathrm{pH}$, Bebelac ${ }^{\circledR} 5$ follow-on milk did not cause a significant roughness on the compomer material and showed values close to that of the distilled water group (Figure 1).

\section{DISCUSSION}

Compomer is undoubtedly the most frequently used material in restoration of the deciduous teeth. ${ }^{15}$ Endurance and preventiveness of this material will both increase the patient's comfort and effect the dentist's long-term success. Acidic foods, which are mostly consumed by children, may harm not only the teeth and the surrounding tissues but also the filling material. ${ }^{16}$ As to the medicines frequently used by children, Ferro Sanol ${ }^{\circledR} B$, used in iron deficiency treatment, is prescribed for the children from 6 months- 15 years of age. ${ }^{17}$ Correr et al. ${ }^{18}$ showed that acidic foods effect the surface roughness of resin composites, compomer and resin-modified glass ionomer materials. In this study, highly acidic Ferro Sanol ${ }^{\circledR}$ B $(\mathrm{pH}=2)$ caused nanocracks on the surface of the compomer material. Ferro Sanol ${ }^{\circledR}$ $\mathrm{B}$, which has the highest difference $(23.3 \mathrm{~nm})$ between initial and post-application surface roughness, can also affect the endurance of the compomer material. Therefore, patient's parents should be warned to take several measures as follows: the medicine should be swallowed without keeping in the mouth, nutrients to neutralize the acidity of the oral environment should be consumed afterwards, and the patient should rinse his/her mouth with water. On the other hand, Calpol ${ }^{\circledR}$, frequently used by children as analgesic, caused roughness on the compomer material compared to the distilled water group $(5.3 \mathrm{~nm})$. Being acidic, Calpol ${ }^{\circledR}$ did not cause surface roughness as much as Ferro Sanol ${ }^{\circledR}$ B. However, SEM images reveal that due to its sucrose content, Calpol ${ }^{\circledR}$ leaves residuals on the compomer material. When consuming foods and medicines with sugar content, oral and dental health should be considered. Augmentin ${ }^{\circledR}$ is the most frequently used broad spectrum antibiotic. Santos et al. ${ }^{19}$ also showed that pediatric syrup containing amoxicillin increased the surface roughness of compomer material. Performing oral cleaning after using this medicine, showing values close to the distilled water group when the surface roughness is taken into consideration $(1.0 \mathrm{~nm})$, will be appropriate.

The compomer samples showing the maximum surface roughness difference in the nutrient group were the Cappy ${ }^{\circledR}$ orange juiceapplied samples. In the SEM images of the samples with high surface roughness difference $(21.4 \mathrm{~nm})$, fragmentations were observed in the attachment points. Cappy ${ }^{\circledR}$ orange juice, containing citric acid, caused damages on the compomer material due to high acidity $(\mathrm{pH}=3.5)$. Such food should be consumed less, and awareness should be raised among parents. It is believed that the connection between the treated teeth and the compomer material may be destroyed in case nutrients causing surface defects on the compomer material are consumed very often.

Defects were detected on the surface of the compomer material in contact with Danino ${ }^{\circledR}$ strawberry yogurt. Surface roughness difference was found to be high in the measurements performed using profilometer $(13.4 \mathrm{~nm})$. Due to its sugar content and thickness, this food left nonisolated and invisible residuals on the compomer material. When consumed frequently, such food may cause propagation of oral bacteria and both tooth tissue and compomer material be damaged.

Nesquik ${ }^{\circledR}$ chocolate milk, having an acidity close to distilled water group $(\mathrm{pH}=6.5)$ showed a surface roughness difference of $2.2 \mathrm{~nm}$, which was supported by SEM images. Bebelac ${ }^{\circledR} 5$ follow-on milk with the same $\mathrm{pH}$ value as the distilled water group $(\mathrm{pH}=7)$ hardly damaged the compomer material $(1.8 \mathrm{~nm})$ but caused residuals due to its thickness and additives in its content. Residuals were observed in some samples although each of them was washed with distilled water for 10 seconds after nutrients and medicines were applied. Although it is recommended to consume water after feeding or taking medication, 
a good oral cleansing thereafter will protect the oral and dental health and prolong the life of the restorative material.

\section{CONCLUSIONS}

Highly acidic medicines and nutrients cause corrosions in compomer restoration. Ferro Sanol $B \circledR$ and Cappy ${ }^{\circledR}$ orange juice effected the surface of compomer material most, compared in their group samples. However, more detailed studies should be conducted on this topic.

\section{ACKNOWLEDGEMENTS}

Part of this study was presented in a poster presentation at 23rd Congress of the Turkish Pedodontics Association - TPD. OP40.0153 Sept 24-28, 2016. Kusadasi, IZMIR.

\section{CONFLICTS OF INTEREST}

None

\section{Besin ve İlaçların Kompomer Yüzeyine Etkisi $\ddot{O} Z$}

Amaç: Bu çalışmanın amacı çocukların sıklıkla tükettiği gıda ve ilaçların çocuk diş hekimliğinde slklkkla kullanilan bir restoratif materyal olan Poliasit Modifiye Kompozit Rezin (kompomer)'in yüzey pürüzlülü̈̆̈̈ üzerine etkisini araştırmaktır. Gereç ve Yöntemler: Çalışmada kullanılan solusyonlar tablo I'de verilmiştir. Restorasyon materyali olarak VOCO Glasiosite ${ }^{\circledR}$ Caps kompomerden diskler oluşturuldu Tüm besin ve ilaçların asiditesi ölçüldü. Materyal, üreticinin önerdiği doğrultuda Led-C ışık cihazı ile 40 sn süresince tek yönden polimerize edildi. Kompomer plaktan kontrol grubuyla birlikte 8 grup olacak şekilde, 10 'ar örnek elde edildi. Örnekler üzerindeki pürüzlülük Bruker ${ }^{\circledR}$ stylus profilometre ile ölçüldü ve değerler nanometre $(\mathrm{nm})$ cinsinden kaydedildi. Sonrasinda solüsyonların 1 ylllk yaklaşı kullanım süreleri hesaplanarak örnekler hazırlanan solüsyonlarda, kontrol grubu ise distile suda ağzı kapalı şekilde bekletildi. Pürüzlülük ölçümleri tekrarlandl. Her iki pürüzlülük değerleri arasındaki fark hesaplanarak istatistiksel ölçümler buna göre yapıldl. Gruplar arası fark hesaplanirken Shapiro-Wilk test and Paired Sample t-Test testi kullanuldl. Bulgular: Ferro Sanol ${ }^{\circledR}$ B ilaç grubunun en yüksek yüzey pürüzlülüğ̈̈ne neden olan ilaç olarak bulundu (23,3 nm). Cappy® portakal suyu ise besin grubunun en yüksek yüzey pürüzlülüğ̈̈ gösteren besini oldu (21,4 nm). SEM görüntüleri de bu sonuçları desteklemektedir. Sonuçlar: Solüsyonların kompomer dolgu yüzeylerinde yüzey pürüzlülüğüne etkisi çeşitlilik sergilemekte olup, yüzey pürüzlülüğünün yanında aşınma miktarının da araştırıldığı ilave çalışmalara ihtiyaç vardır. Yüzey pürüzlülüğ̈̈nü artıran solüsyonların tüketiminde daha dikkatli davranılmalıdır.

Anahtar kelimeler: Yüzey özellikleri, kompomerler, besinler, ilaç kullanma.

\section{REFERENCES}

1. Gonulol N, Yilmaz F. The effects of finishing and polishing techniques on surface roughness and color stability of nanocomposites. J Dent 2012;40:64-70.

2. Valentini F, Oliveira SG, Guimaraes GZ, Barbosa RP, Moraes RR. Effect of surface sealant on the color stability of composite resin restorations. Braz Dent J 2011;22:365-368.

3. Soncini, JA, Maserejian, N. N, Trachtenberg, F, Tavares, M, Hayes, C. The longevity of amalgam versus compomer/composite restorations in posterior primary and permanent teeth: findings From the New England Children's Amalgam Trial. J Am Dent Assoc 2007;138,763-772.

4. Toledano M, De La Torre FJ, Osorio R. Evaluation of two polishing methods for resin composites, Am J Dent 1994;7:328-330.

5. Shintani H, Satou J, Satou N, Hatashihara H, Inoue

$\mathrm{T}$. Effects of various finishing methods on staining and accumulation of Streptococcus mutans HS-6 on composite resins. Dent Mater 1985;1:225-227.

6. Dijken V, J.W.V., Sjöström S. Development of gingivitis around aged restorations of resin-modified glass ionomer cement, polyacid-modified resin composite (compomer) and resin composite. Clin Oral Investig 1998; 2:180-183.

7. Vieira A, Lugtenborg M, Ruben JL, Huysmans MC. Brushing abrasion of eroded bovine enamel pretreated with topical fluorides. Caries Res 2006; 40: 224-230.

8. Geurtsen W, Leyhausen G, Garcia Godoy F. Effect of storage media on the fluoride release and surface microhardness of four polyacid-modified composite resins (“compomers"). Dent Mater 1999;15:196-201.

9. Honório HM, Rios D, Francisconi LF, Magalhães AC, Machado MA, Buzalaf MA. Effect of prolonged erosive $\mathrm{pH}$ cycling on different restorative materials. J Oral Rehabil 2008;35:947-953. 
10. Munack J, Haubert H, Dogan S, Geurtsen W. Effects of various storage media on surface hardness and structure of four polyacidmodified composite resins ("compomers") Clin Oral Investig 2001;5:254259.

11. Yanikoglu N, Duymus Z, Yilmaz B. Effects of different solutions on the surface hardness of composite resin materials. Dent Mater J 2009;28:344351.

12. Wongkhantee S, Patanapiradej V, Maneenut C, Tantbirojn D. Effect of acidic food and drinks on surface hardness of enamel, dentine, and toothcoloured filling materials. J Dent 2006;34:214-220.

13. Kaur H, Nandlal, B. Effect of dietary solvents on the strengtşh of nanocomposite, compomer, glass ionomer cement: An in-vitro study. J Conserv Dent 2013;16:527-531.

14. Aliping-Mckenzie M, Linden RWA, Nicholson JW. The effect of Coca-Cola and fruit juices on the surface hardness of glass-ionomers and 'compomers. J Oral Reh 2004; 31:1046-1052.
15. El-Kalla H, Garcia-Godoy F. Mechanical properties of compomer restorative materials.Oepr Dent 1999;24:2-8.

16. Maupomé G, Díez-de-Bonilla J, Torres-Villaseñor G, AndradeDelgado LC, Castaño VM. In vitro quantitative assessment of enamel microhardness after exposure to eroding immersion in a cola drink. Caries Res1998;32:148-153.

17. Kavaklı K, Yılmaz D, Çetinkaya B, Balkan C, Sözmen, EY, Sağın FG. Safety profiles of Fe2+ and $\mathrm{Fe} 3+$ oral preparations in the treatment of iron deficiency anemia in children. Pediatr Hematol Oncol 2004;21:403-410.

18. Correr GM, Bruschi Alonso RC, Baratto-Filho F, Correr-Sobrinho L, Sinhoreti MAC, Puppin-Rontani R. M. In vitro long-term degradation of aesthetic restorative materials in food-simulating media. Acta Odontol Scand 2012;70:101-108.

19. Santos MPA, Patrocínio A. L, da Silva Fidalgo TK, Camargo Jr S. S, Maia LC. Surface Degradation of Resin-based Materials by Pediatric Syrup Containing Amoxicillin under Erosive Challenge. Pesqui Bras Odontopediatria Clin Integr 2017;17:3446-345. 